\title{
Vegetation resilience to absorbing carbon dioxide emissions in the Gajahmada Street
}

\author{
Miftachurahma Widanirmala ${ }^{1,3^{*}}$, Maryono Maryono ${ }^{2,3}$, and Fuad Muhammad ${ }^{1,3}$ \\ ${ }^{1}$ Master Program of Environmental Science, School of Postgraduate, Diponegoro University, \\ Indonesia \\ 2 Department of Urban and Regional Planning, Faculty Engineering, Diponegoro University, \\ Indonesia \\ 3 Centre for Green Infrastructure Resilience and Development, School of Postgraduate, Diponegoro \\ University, Indonesia
}

\begin{abstract}
Abstrak. Gajahmada Street is one of the main streets in the city of Semarang. The location is very strategic, which connects the Golden Triangle Region in Semarang City which is the center of the city. As a city center, transportation activities in the area are very high. Transportation activities produce carbon dioxide emissions. The accumulation of carbon dioxide emissions is dangerous for health and the environment. Semarang City Government provides green open space along the road section to reduce carbon dioxide emissions. The purpose of this study was to determine the vegetation resilience to absorbing carbon dioxide at that location. The data collection method uses literature collection and field observations. The results showed the ability of green open space to absorb carbon dioxide emissions is $1.218,7$ tons/ha/year. While the emissions produced are 6.832 tons/year, meaning that there is residual carbon dioxide that is not absorbed, that is $5.613,3$ tons/year.
\end{abstract}

Keywords: vegetation resilience, carbon absorption, emissions, Gajahmada Street

\section{Introduction}

Global warming is an increase in the earth's average temperature due to the concentration of greenhouse gases (GHGs) [1]. Increase in average temperature - based on increasing concentrations of GHGs [2]. GHGs consists of $\mathrm{CO}_{2}, \mathrm{~N}_{2} \mathrm{O}, \mathrm{NO}_{2}, \mathrm{CH} 4, \mathrm{CFC}$, etc. The gas will accumulate in the earth and form a transparent layer in the earth's atmosphere which is likened to the glass layer. As a result, sunlight cannot be reflected and becomes trapped on earth. This causes an increase in the temperature of the earth.

\footnotetext{
* Corresponding author: widanirmalawini@gmail.com
} 
Carbon dioxide is the gas that can last the longest in the atmosphere. $\mathrm{CO}_{2}$ can last 50-200 years, $\mathrm{N}_{2} \mathrm{O}$ for 114-120 years, $\mathrm{CH} 4$ and $\mathrm{CFC}$ substitutes for 12 years [3]. Basically, carbon dioxide is an important gas for photosynthesis. However, excessive levels can be dangerous for the environment, which triggers global warming, acid rain, etc. For health, exposure to low levels of carbon dioxide gas can cause dizziness, hyperventilation, eye and throat irritation, minor lung disorders, central nervous system injuries, etc. While exposure to high levels can cause oxygen supply to be obstructed, which can cause seizures - even death.

Based on IPCC data at 2007, from 1970 to 2004 there has been an increase in carbon dioxide equivalent of $77 \%$, from $21 \mathrm{Gt}$ of CO2-eq to $31 \mathrm{Gt}$ of CO2-eq [2]. In Indonesia, based on the 2018 Greenhouse Gas inventory report by the Ministry of Environment and Forestry, during the last 17 (seventeen) years there was an increase in carbon dioxide of 124,879 $\mathrm{Gg}$ $(124,879,000$ Tons). Transportation activities were the second largest contributor to the increase in carbon dioxide, which amounted to $17.20 \%$.

For modern urban society, transportation is a vital means of movement that cannot be separated from daily activities. Especially in Indonesia, almost all of the cities are developed based on the pattern of land transportation networks. This creates a dilemma, on the one hand the land transportation system has become a dependency for the community, but on the other hand land transportation is suspected to threaten urban ecological conditions.

Green open space is one solution to reduce global warming [4]. Green open space is an area that extends or lines and or groups, the use of which is more open, a place to grow plants, both naturally and intentionally planted. The provision of green open space is suspected to reduce carbon dioxide [5]. Green open space has an important role to improve the quality of life in urban areas, one of them as a very effective air purifier [6]. Green vegetation, especially trees, has the ability to absorb large amounts of carbon dioxide. One tree has the ability to absorb carbon dioxide of 569 tons / ha / year.

Trees are vegetation that have an important role in the process of reducing the concentration of $\mathrm{CO} 2$ in the air through the process of photosynthesis. Trees have the highest $\mathrm{CO} 2$ absorption compared to other types of vegetation (shrubs and groundcovers), because they have greater biomass compared to other vegetation. The part of the tree in charge of absorbing $\mathrm{CO} 2$ is the leaves through the stomata. Then the carbon will be stored in the biomass, namely in the stems and leaves. Compared to leaves, stems can deviate far more carbon [5]. Even 50\% of the total dry stem consists of carbon. The amount of carbon stored in biomass is called carbon storage. While the ability of plants to absorb carbon is called carbon sequestration [7].

Based on the Spatial Planning Law, the green space requirements that must be met by the City are $30 \%$ of the total area, with the provisions that $20 \%$ are public and $10 \%$ are private. Semarang City is one of the cities in Indonesia that has fulfilled the provision of public green open space [8]. Based on information from the City of Semarang Department of Commerce, the number of green open space in the city of Semarang is $35 \%$, which means it has exceeded the recommended minimum. Viewed in quantity, the presence of green open space in the city of Semarang has met the provisions. However, judging from its function, is the presence of green space effective enough to reduce the $\mathrm{CO}_{2}$ emissions produced? For this reason, this study aims to determine the ability of $\mathrm{CO}_{2}$ absorption by vegetation. Case study was carried out on the Jl. Gajah Mada. The location was chosen because transportation activities on the road section are quite high, resulting in considerable $\mathrm{CO}_{2}$ emissions. Gajahmada Street is one of the main streets in the city of Semarang. Its location is very strategic, which connects the Golden Triangle Region in Semarang City which is the center of the city. In addition, the use of land on these roads is also very complex, giving rise to high generation and pull 


\section{Method}

\subsection{Data collection methods}

Data collection methods used in this study are literature studies, observations and interviews. Literature study is carried out by gathering literature related to the topic to be studied. Observations were made by observing daily traffic and inventorying the types of vegetation on Gajah Mada Street. Interviews were conducted with relevant agencies responsible for managing green open spaces on Gajah Mada Street.

\subsection{Data analysis method}

To find out the adequacy of green open space in absorbing $\mathrm{CO}_{2}$ emissions in Gajahmada Street, it is done by: 1) calculating the $\mathrm{CO}_{2}$ absorption by vegetation, 2) calculating $\mathrm{CO}_{2}$ emissions resulting from transportation activities on Jl. Gajahmada, 3) analysis of the adequacy of green space to absorb emissions.

\section{Analysis of vegetation resilience (carbon stocks by trees)}

Plants need $\mathrm{CO}_{2}$ to carry out photosynthesis. The results of the absorption of $\mathrm{CO}_{2}$, will be converted into carbohydrates which will then be spread and piled up in the body of the plant. The process is called C-sequestration. Therefore, measuring carbon still stored in the body of living plants (biomass) can describe the amount of $\mathrm{CO}_{2}$ that can be absorbed by plants. According to the [9], half the biomass of trees is $\mathrm{CO}_{2}$. Calculation of $\mathrm{CO}_{2}$ deposits in plant biomass is carried out using a formula developed by [9]:

$$
=0,5
$$

Note :

$\mathrm{C}:$ carbon stock $(\mathrm{C} / \mathrm{Ha})$

$\mathrm{W}$ : biomass $(\mathrm{kg})$

0,5 : Coefficient of carbon in plants

Tree biomass is calculated using the allometric formula [5]:

Note :

$$
=0,11 \rho 2,62
$$

BK : biomass $(\mathrm{kg})$

$\mathrm{D}:$ diameter $(\mathrm{cm})$

$\rho:$ BJ wood $(\mathrm{g} \mathrm{cm}-3)$

Furthermore, to find out the potential uptake of $\mathrm{CO}_{2}$ will be done by adding up carbon stocks in each tree:

(carbon stocks by A tree x number of A tree) + (carbon stocks by A tree x number of $A$ tree $)+$

\section{Quantity analysis of $\mathrm{CO} 2$ emissions}

Calculate CO2 emissions generated using the Tier 2 Method [10], with the formula: 
Note :

$$
Q=N i x \text { Fei } x \text { L } x \mathrm{Kl}
$$

Q : emission amount (g/hour)

$\mathrm{Ni}$ : number of vehicles (vehicles/hour)

Fei : emission factor of vehicles (g/liter)

$\mathrm{Kl}$ : fuel usage (liter $/ 100 \mathrm{~km})$

$\mathrm{L} \quad$ : long road $(\mathrm{km})$

Table 1. Emission factor

\begin{tabular}{|l|c|c|c|c|}
\hline \multirow{2}{*}{ Type of vehicles } & \multicolumn{4}{c|}{ Emission factor } \\
\cline { 2 - 5 } & $\mathbf{C H}_{\mathbf{4}}$ & $\mathbf{C O}$ & $\mathbf{N}_{\mathbf{2}} \mathbf{O}$ & $\mathbf{C O}_{\mathbf{2}}$ \\
\hline Fuel & 0,71 & 462,63 & 0,04 & 2597,86 \\
\hline Passenger vehicles & 0,71 & 295,37 & 0,05 & 2597,87 \\
\hline Small commercial vehicle & 0,73 & 281,14 & 0,06 & 2597,88 \\
\hline Big commercial vehicle & 3,56 & 427,05 & 0,07 & 2597,89 \\
\hline Mototcycle & 0,08 & 11,86 & 0,16 & 2924,90 \\
\hline Diesel & 0,04 & 15,81 & 0,16 & 2924,90 \\
\hline Passenger vehicles & 0,24 & 35,57 & 0,12 & 2924,90 \\
\hline Small commercial vehicle & 0,24 & 24,11 & 0,08 & 2924,43 \\
\hline Big commercial vehicle
\end{tabular}

Sumber: [10]

Table 2. Fuel consumption of vehicles

\begin{tabular}{|c|c|c|}
\hline No & Type of vehicles & $\begin{array}{l}\text { Fuel consumption of vehicles } \\
\text { (liter/100 km) }\end{array}$ \\
\hline \multirow[t]{3}{*}{1} & \multicolumn{2}{|l|}{ Passenger car } \\
\hline & Fuel & 11,79 \\
\hline & Diesel & 11,36 \\
\hline \multirow[t]{3}{*}{2} & \multicolumn{2}{|l|}{ Big bus } \\
\hline & Fuel & 23,15 \\
\hline & Diesel & 16,89 \\
\hline 3 & Medium bus & 13,04 \\
\hline \multirow{3}{*}{4} & Small bus & \\
\hline & Fuel & 11,35 \\
\hline & Diesel & 11,83 \\
\hline 5 & Bemo or bajaj & 10,99 \\
\hline \multirow{3}{*}{6} & Taxi & \\
\hline & Fuel & 10,88 \\
\hline & Diesel & 6,25 \\
\hline 7 & Tronton truck & 15,82 \\
\hline 8 & Medium truck & 15,15 \\
\hline \multirow{3}{*}{9} & Small truck & \\
\hline & Fuel & 8,11 \\
\hline & Diesel & 10,64 \\
\hline 10 & Mototcycle & 2,66 \\
\hline
\end{tabular}

Sumber: [10] 


\section{Analysis of the adequacy of green open space to absorb $\mathrm{CO}_{2}$ emissions}

An analysis of the adequacy of green space to absorb $\mathrm{CO}_{2}$ emissions is done by comparing the carbon stock of green space on Gajahmada Street with $\mathrm{CO}_{2}$ emissions resulting from transportation activities.

\section{Results and Discussion}

\subsection{Type of vegetation in green open spaces pedestrians on Gajahmada Street}

Gajahmada street is located in Sekayu Village, Central Semarang District. The location is very strategic, which is located in the city center and connects the golden triangle of the City of Semarang. Based on the Minister of Public Works Regulation No: 05 / PRT / M / 2008, the type of green open space in the study location is pedestrian open space. Green open spaces is provided as one with the pedestrian space along Jalan Gajahmada. The dominance of vegetation in the form of shade vegetation which has the function to provide shade for pedestrians, while reducing $\mathrm{CO} 2$. However, it is very regrettable that the density of trees in this green space is still low.

The type of tree that is on the Gajahmada Street consists of 14 species with a total of 141 trees. The vegetation types are Angsana, Ordinary Glodokan, Mahogany, Pulai, Asa, Java, Glodokan Pole, Tabebuya, Squirrel Tail Palm, Sawo Duren, Cambodia, Acacia, Mango Apple, Mango, and Yellow Coconut. Existing vegetation is dominated by Angsana Tree and Ordinary Glodokan. Vegetation in the study area is included in the category of medium and large trees with varying diameters. Medium category trees have an average diameter of 21 $\mathrm{cm}$, while large category trees are $60 \mathrm{~cm}$.

\subsection{Analysis of vegetation resilience (carbon stocks by trees)}

Vegetation Resilience of carbon absorption is the ability of trees to absorb CO2 in their bodies. The following is presented the potential for carbon uptake in the pedestrian green space on Gajahmada Street. 
Table 3. $\mathrm{CO} 2$ absorption by vegetation

\begin{tabular}{|c|c|c|c|c|}
\hline No. & Local name & Latin name & $\begin{array}{l}\text { Total of } \\
\text { tree }\end{array}$ & $\begin{array}{c}\text { Absorption CO2 on } \\
\text { Gajahmada Street } \\
\text { (kg/year) }\end{array}$ \\
\hline 1. & Angsana & Pterocarpus indicus & 52 & $98.950,3$ \\
\hline 2. & Glodokan Biasa & Polyalthia sp. & 14 & $16.148,4$ \\
\hline 3. & Mahoni & Swietenia macrophylla & 23 & 5.382 \\
\hline 4. & Pulai & Alstonia scholaris & 20 & $9.699,5$ \\
\hline 5. & Asam Jawa & Tamarindus indica & 11 & $2.950,8$ \\
\hline 6. & Glodokan Tiang & Polyalthia longifolia & 8 & $1.052,2$ \\
\hline 7. & Tabebuya & Handroanthus sp. & 2 & 313 \\
\hline 8. & Palem Ekor Tupai & Wodyetia bifurcata & 3 & 119,4 \\
\hline 9. & Sawo Duren & Chrysophyllum cainito & 1 & 16,3 \\
\hline 10. & Kamboja & Plumeria & 1 & 14,2 \\
\hline 11. & Akasia & Acacia sp. & 3 & 4.918 \\
\hline 12. & Mangga Apel & Mangifera indica & 1 & 6.403 \\
\hline 13. & Mangga & Mangifera sp. & 1 & 138,9 \\
\hline 14. & Kelapa Kuning & Cococs nucifera & 1 & 136,8 \\
\hline \multicolumn{3}{|c|}{ Total } & 141 tree & $\begin{array}{c}146.243,4 \mathrm{~kg} / \text { year or } \\
146,3 \text { tons/year }\end{array}$ \\
\hline \multicolumn{4}{|c|}{$\begin{array}{ll}\text { Wide open green space: } 1,2 \times 1000 \mathrm{~m}= & \mathrm{m}^{2} / 0,12 \\
1.200 & \mathrm{Ha} \\
\end{array}$} & $1.218,7$ tons $/$ ha/year \\
\hline
\end{tabular}

Table 3, potential CO2 uptake on Gajahmada Street is 1,218.7 tons/ha/year. Basically, plants need $\mathrm{CO} 2$ gas for photosynthesis. Plants need $\mathrm{CO} 2$ to carry out photosynthesis. The results of the absorption of $\mathrm{CO} 2$ will be converted into carbohydrates which will then be spread and piled up in the body of the plant. Each type of vegetation has the ability to absorb different CO2. According to Hidayati et al (2013), the ability of carbon dioxide uptake from each tree is influenced by the number of stomata and the ability of stomata to open a plant. The greater the opening of the stomata, the greater the ability of carbon dioxide absorption. In addition, the size of the rod also affects the carbon storage capacity. Because $50 \%$ of the carbon stock is stored in the trunk.

\subsection{CO2 emissions on Gajahmada Street}

$\mathrm{CO} 2$ emissions on Gajahmada Street is sourced from transportation activities. Gajahmada Street is the main road that connects the Golden Triangle Region of Semarang City. In addition, the use of surrounding land is quite complex, namely: settlement, trade and services, education, and worship. As a result, the generation and pull of traffic in this area is quite high. The rise and pull of traffic can be seen from the high volume of vehicles passing through this road section. The following is the vehicle volume on Gajahmada Street: 
Table 4. CO2 emissions on Gajahmada Street

\begin{tabular}{|c|l|c|c|}
\hline No. & \multicolumn{1}{|c|}{ Type of vehicles } & Volume of vehicles* & CO Emission (g/hour) \\
\hline 1. & $\begin{array}{l}\text { Kendaraan Ringan } \\
\text { (LV) }\end{array}$ & 1142 & 175.805 \\
\hline 2. & Kendaraan Berat (HV) & 12 & 142 \\
\hline 3. & Sepeda Motor & 2253 & $320 / 164$ \\
\hline 4. & Angkutan Umum & 14 & 166 \\
\hline \multicolumn{2}{|c|}{ Total } & $496.277 \mathrm{~g} /$ hour or \\
& emission CO & $4.347,4$ tons/year \\
\hline \multicolumn{2}{|c|}{ Conversion CO to CO2 } \\
\hline
\end{tabular}

*Source: Field Observation (2017)

Table 4, vehicles passing through Gajahmada Street consist of long vehicles, heavy vehicles, motorbikes, and public transportation. The types of vehicles that pass this road are 2253 units of motorbikes and 1142 private cars. Of the many vehicles that pass through these roads cause exhaust gases that contain emissions, in the form of: Carbon monoxide (CO), Sulfur (SOx), Nitrogen oxide (Nox), Hydro carbon (HC), dust (TSP) and lead (PB). CO gas when oxidized in the earth's atmosphere can turn into $\mathrm{CO}_{2}$ gas which is a greenhouse gas, triggering global warming.

Based on the calculation results, $\mathrm{CO}$ emissions are generated from vehicles passing through J1. Gajahmada of 4,346.4 tons/year. If converted into $\mathrm{CO}_{2}$ it becomes 6,832 tons/year. This figure is quite high, and can continue to increase given the trend in the number of vehicles in the city of Semarang is exponential.

\subsection{Adequacy of green open space to absorbing $\mathrm{CO}_{2}$ emissions on Gajahmada Street}

Adequeacy of green open space : $\mathrm{CO}_{2}$ absorption $-\mathrm{CO}_{2}$ emissions

$$
: 1.218,7 \mathrm{ton} / \mathrm{ha} / \text { year }-6.832 \text { tons/year }
$$

\section{- 5.613,3 ton/year}

From the calculation of $\mathrm{CO}_{2}$ absorption by vegetation and $\mathrm{CO}_{2}$ emissions on Gajahmada Street is known to have residual $\mathrm{CO}_{2}$. That is equal to 5,613.3 tons / year. That is, the amount of green open space provided is insufficient so there is left over. Basically, plants need $\mathrm{CO}_{2}$ gas for photosynthesis. However, excess $\mathrm{CO}_{2}$ levels cannot be absorbed and can survive in the atmosphere for up to 200 years. Long-term accumulation of $\mathrm{CO}_{2}$ gas can cause environmentally and health problems. For the environment it can cause global warming, acid rain, etc. For health, exposure to low levels of $\mathrm{CO}_{2}$ gas can cause dizziness, hyperventilation, eye and throat irritation, mild lung disorders, central nervous system injuries, etc. While exposure to high levels can cause oxygen supply to be obstructed, which can cause seizures - even death. 


\section{Conclusions and recommendations}

The ability of $\mathrm{CO}_{2}$ absorption by vegetation on Gajahmada Street of 1,218.7 tons / ha / year. While emissions resulting from transportation activities at these locations are 6,832 tons / year. It can be concluded that there are residual emissions as large as 5,613.3 tons / year, so that the presence of vegetation is not optimal in reducing $\mathrm{CO}_{2}$.

Suggestions given, it is necessary to add vegetation to the pedestrian green space on Gajahmada Street. It is very possible, seeing the density of trees is still low. In addition, the proposed selection of trees with high carbon absorption: such as trembesi.

\section{Acknowledgement}

The research is funded by Directorate Research and Community Services, Deputy of Research Development, Ministry of Research and Technology / National Research and Innovation Board with cooperation between Institute of Research and Community Services Diponegoro University taskforce letter No. 255-141/UN7.6.1/PP/2020

\section{References}

1. Rusbiantoro, D, Global warming for beginner (2008)

2. IPCC. Guidelines for National Greenhouse Gas Inventories. Volume 2: Energy (2008).

3. K. Sejati, Global Warming, Food, and Water Problems, Solutions, and The Changes of World Geopolitical Constellation (2011)

4. N. Kusumaningrum, Jurnal Permukiman, Potensi tanaman dalam menyerap CO2, dan CO untuk mengurangi dampak pemanasan global. Vol 3 (2) pp. 97-105 (2008).

5. K. Hairiah et all, Pengukuran cadangan karbon, Wolrd Agroforestry Centre (2011).

6. Law of Permen PU No.5/PRT/M, 2008 Tentang Pedoman Penyediaan dan Pemanfaatan Ruang Tebuka Hijau di Kawasan Perkotaan.

7. K. Hairiah, S. Rahayu, Pengukuran karbon tersimpan di berbagai penggunaan lahan, Wolrd Agroforestry Centre (2007).

8. Law No 26 of 2007 concerning Spatial planning

9. IPCC. Guidelines for National Greenhouse Gas Inventories (2006).

10. B.A. Laksono, Jurnal Teknik Lingkungan ITS, Analysis of the suffiency of vegetation in absorbing carbon monoxide (CO) due to motor vehicles activity on the Ahmad Yani Street Surabaya (2014)

11. Kementerian Lingkungan Hidup dan Kehutanan Direktorat Jenderal Pengendalian Perubahan Iklim Direktorat Inventarisasi Gas Rumah Kaca dan MPV. Laporan Inventarisasi Gas Rumah Kaca dan Monitoring, Pelaporan Verifikasi Tahun (2018) 